\title{
Pengaruh Kualitas Informasi Akuntansi, Akuntabilitas dan Transparansi Pelaporan Keuangan Terhadap Tingkat Penerimaan Dana Zakat
}

\author{
Efri Agihidayantari', Putu Sukma Kurniawan² \\ 1,2 Program Studi S1 Akuntansi, Universitas Pendidikan Ganesha \\ Singaraja, Indonesia \\ e-mail:1| efri.id65@gmail.com, ${ }^{2}$ | putusukma@undiksha.ac.id\}
}

\begin{abstract}
Abstrak
Penelitian ini bertujuan agar mengetahui pengaruh kualitas informasi akuntansi, akuntabilitas dan transparansi pelaporan keuangan terhadap tingkat penerimaan dana zakat pada BAZNAS Kabupaten Buleleng. Penelitian ini merupakan penelitian kuantitatif dimana sumber datanya berasal dari data primer berupa penyebaran kuesioner secara langsung dan melalui google form ke responden. Populasi di penelitian ini yaknisemua muzakki yang membayar zakatnya melalui BAZNAS Kabupaten Buleleng. Sampel yang dipilih denganTeknik purposive serta didapat jumlah sampel sebanyak 182 orang. Analisis data yang digunakan terdiri dari: uji kualitas data, analisis deskriptif, uji asumsi klasik, dan uji hipotesis. Dimana uji hipotesis meliputi uji regresi linear berganda, uji t dan uji koefesien determinasi dengan bantuan SPSS versi 24 for windows. Hasil penelitian menunjukkan bahwasannya 1. Kualitas Informasi Akuntansi berpengaruh positif terhadap tingkat penerimaan dana zakat 2. Akuntabilitas berpengaruh positif terhadap tingkat penerimaan dana zakat dan 3 . Transparansi pelaporan keuangan berpengaruh positif terhadap tingkat penerimaan dana zakat.
\end{abstract}

Kata Kunci: kualitas informasi akuntansi, akuntabilitas, transparansi dan tingkat penerimaan dana zakat.

Abstract
The purpose of this study is to determine the efect quality of accounting information, accountabillity and transparency in financial report on the level of recipt of zakat funds at the BAZNAS of Buleleng Regency. This research is a quantitative studying in which the source of the data comes from primarry data in the form of distributing questionnaires directly and via google form to respondents. The population in this study is muzakki who pay their zakat through the BAZNAS of Buleleng Regency. The sample selected by purposive technique and obtained a total sample is 182 people. Analysis of the data used consists of: data quality test, descriptive analysis, classic assumption test, and hypothesis testing. Where the hypothesis test includes multiple linear regression test, $t$ test and test the coeficient of determination with the help of SPSS version 24 for windows. The results of this study indicate that 1. Quality of Accounting Information has a positive efect on the level of receipt of zakat funds 2. Accountability has a positive efect on the level of receipt of zakat funds and 3. Transparency of financial reporting has a positive efect on the level of receipt of zakat funds.

Keywords: quality of accounting information, accountability, transparency and the level of receipt of zakat funds.

\section{Pendahuluan}

Kabupaten Buleleng merupakan salah satu daerah yang memiliki Organisasi Pengelola Zakat (OPZ) dalam menghimpun dana zakat. Meskipun demikian, muzakki tidak memanfaatkan adanya OPZ tersebut untuk membayar zakatnya. Kebanyakan muzakki membayar zakatnya langsung kepada mustahiq (penerima zakat) yang berdampak kepada tingkat penerimaan dana zakat yang diterima BAZNAS Kabupaten Buleleng. Potensi zakat pada Kabupaten Buleleng dilihat dari jumlah penduduk yang beragama islam sekitar 22.742 
orang. Tetapi tidak semua penduduk yang beragama islam membayar zakatnya melalui BAZNAS Kabupaten Buleleng, masih banyak muzakki yang membayar zakatnya tidak melalui unit pengumpul zakat terlebih dahulu. Apabila sebanyak 380 orang yang membayar zakatnya melalui BAZNAS dapat di rata-ratakan jumlah zakat maal dan zakat fitrah sekitar Rp. 100.000,00 dalam setahun per orangnya, dengan demikian total zakat yang dikumpulkan setahunnya sekitar Rp. 38.000.000. Nominal tersebut merupakan nominal yang terbilang cukup tinggi untuk potensi zakat di wilayah Kabupaten. Tetapi, pada kenyataannya realisasi jumlah danayang terkumpul pada BAZNAS Kabupaten Buleleng tidak sesuai dengan potensi yang ada.

Menurut Ketua Umum BAZNAS Kabupaten Buleleng, Ustad Maksum Amin mengatakan rendahnya tingkat dana zakat yang di terima oleh BAZNAS Kabupaten Buleleng dikarenakan masih banyak muzakki yang mempertanyakan mengenai kualitas informasi akuntasi, akuntabilitas serta transparansi dari pelaporan keuangan yang dibuat. Rata-rata masyarakat Islam yang berada di Kabupaten Buleleng masih membayar zakatnya tidak melalui lembaga amil zakat, melainkan diserahkan kepada penerima zakat langsung, hal tersebut mengakibatkan kepada jumlah dana zakat yang diterima.

Kualitas informasi akuntansi dalam Badan Amil Zakat Nasional (BAZNAS) penting untuk disampaikan kepada muzakki (pemberi zakat) yang akan membayar zakat ke BAZNAS, karena masyarakat akan lebih membutuhkan informasi yang jelas dan akurat. Dalam penerimaan dana zakat, kualitas informasi akuntansi ini dimaksudkan dapat membantu muzakki dalam membuat keputusan untuk membayar zakat di BAZNAS sehingga akan berdampak pada penerimaan dana zakat. Dengan kata lain, Informasi yang dibuat secara jelas dan akurat akan menjadi pertimbangan masyarakat dan muzakki dalam membayar zakatnya. Oleh karena itu, hal tersebut akan dapat meningkatkan penerimaan dana zakat (Nurhisammudin, 2017). Dalam menerapkan kualitas informasi akuntansi harus memperhatikan karakteristik kualitatif. Akan tetapi, jika salah satu karakteristik kualitatif tidak diterapkan maka akan menjadi sebuah pertanyaan yang menjadi permasalahan yang berdampak pada penerimaan dana zakat. Hal inilah yang menjadi permasalahan yang dipertanyakan oleh muzakki terkait dengan informasi yang dihasilkan oleh BAZNAS Kabupaten Buleleng, informasi yang dihasilkan oleh BAZNAS Kabupaten Buleleng belum seluruhnya menerapkan asas yang terdapat dalam karakteristik kualitatif.

Menurut Nugraha (2019), bahwa akuntabilitas adalah suatu keharusan bagi setiap lembaga amil zakat untuk melaporan laporan keuangan dan mempertanggungjawabkan segala aktivitas dan kegiatan yang dilakukan organisasi terkait dengan keberhasilan mapun kegagalan misinya kepada pihak yang berwenang. Dalam penerimaan dana zakat, akuntabilitas dimaksudkan agar dapat meningkatkan kinerja dalam lembaga amil zakat dalam melaporkan segala pertanggungjawaban berupa amanah yang diberikan oleh muzakki yang nantinya akan berdampak kepada muzakki yang percaya terhadap lembaga amil zakat untuk membayar zakatnya melalui BAZNAS Kabupaten Buleleng sehingga akan meningkatkan penerimaan dana zakat. Dengan kata lain, penerapan akuntabilitas merupakan prinsip yang sangat penting diterapkan untuk menyajikan serta melaporkan segala kegiatan penerimaan dana zakat terutama kegiatan finansial kepada muzakki. Di BAZNAS Kabupaten Buleleng masih terus mengupayakan untuk selalu memberikan pertanggungjawaban secara tepat waktu terkait realisasi dalam penerimaan dana zakat serta kegiatan amal lainnya sebagai bentuk pertanggungjawaban terhadap kebutuhan muzakki.

Menurut Yuliafitri (2016), Transparansi dalam laporan keuangan merupakan upaya dalam melaporan segala informasi terkait keadaan kas secara terbuka dan benar terhadap masyarakat yang didasarkan bahwa masyarakat memiliki kewenangan dan berhak mengetahui terkait akuntabilitas pengelolaan. Dalam penerimaan dana zakat, transparansi ini dimaksudkan agar lembaga amil zakat berperilaku terbuka dalam laporan keuangannya terhadap segala penerimaan dalam pembayaran zakat yang dibayarkan dari muzakki. Apabila unit pengumpul zakat menerapkan prinsip transparansi dalam pelaporan keuangannya maka muzakki akan percaya membayar zakatnya melalui BAZNAS Kabupaten 
Buleleng sehingga akan dapat meningkatkan penerimaan dana zakat. Transparansi laporan keuangan sangatlah dibutuhkan oleh para penerima zakat pada saat menyerahkan zakatnya kepada unit pengumpul zakat, karena prinsip transparansi dibangun atas dasar kebutuhan untuk mendapatkan informasi yang diperlukan tentang penerimaan dana zakat. Artinya, segala kebutuhan informasi mengenai kebutuhan masyarakat luas harus dengan mudahnya diakses oleh para penerima zakat di BAZNAS Kabupaten Buleleng. Setelah dilakukannya observasi awal oleh peneliti, transparansi dalam penerimaan dana zakat pada BAZNAS Kabupaten Buleleng dilakukan hanya dengan memberikan hard copy laporan keuangan secara langsung apabila muzakki ingin mengetahui laporan keuangan yang dibuat. Namun hal tersebut sering kali menimbulkan masalah oleh muzakki laporan keuangan yang dibuat tidak dilaporkan di website resmi BAZNAS Kabupaten Buleleng karena banyak dari muzakki yang membayar zakatnya melalui website dikarenakan tempat tinggal jauh dengan BAZNAS Kabupaten Buleleng. Sehingga masih banyak muzakki lainnya yang masih mempertanyakan terkait transparansi laporan keuangan yang dibuat yang terbilang masih sulit diakses.

Skripsi yang telah dilakukan pada peneliti sebelumnya, diantaranya adalah Novianti (2019) dan Nurhayati (2014) dalam penelitiannya dinyatakan bahwasannya suatu kualitas informasi akuntansi pada penerimaan dana zakat sangat berpengaruh signifikan. Pada penelitian Assegaf (2016) menyatakan bahwasannya dalam keinginan membayar zakat memiliki pengaruh pada akuntabilitas yang diberikan. Begitupula dengan Novianti (2019) menyatakan akuntabilitas berpengaruh signfikan terhadap tingkat penerimaan dana zakat. Natalia (2019) menyatakan bahwasannya transparansi berpengaruh positif pada penerimaan dana zakat. Begitupula dengan penelitian Novianti (2019) menyatakan transparansi berpengaruh signifikan pada tingkat penerimaan dana zakat.

Mengacu pada penelitian sebelumnya oleh Assegaf (2016) "Pengaruh Akuntabilitas dan Transparansi Pengelolaan Zakat Terhadap Minat Muzakki Membayar Zakat" dan penelitian dari Novianti (2019) Pengaruh Kualitas Informasi Akuntansi, Akuntabilitas, Transparansi Pelaporan Keuangan dan Aksebilitas Terhadap Tingkat Penerimaan Dana Zakat Pada BAZNAS Pekanbaru." Persamaan dari penelitian ini dengan penelitian Assegaf (2016) yakni pada penggunaan variabelnya yaitu akuntabilitas dan transparansi dengan ditambahkan variabel Kualitas Informasi Akuntansi yang diambil dari penelitian Novianti (2019). Peneliti memilih menggunakan ketiga variabel tersebut sebagai variabel yang akan mempengaruhi variabel tingkat penerimaan dana zakat karena telah disesuaikan dengan permasalahan yang terjadi di lokasi penelitian.

Perbedaan pada penelitian yang lainnya yakni dilihat dari objek penelitiannya yang digunakan peneliti langsung kepada lembaga amil zakat di BAZNAS bukan melalui Unit Pengumpul Zakat nya, karena selama ini telah banyak peneliti yang berfokus kepada UPZ/OPZ sebagai objek penelitiannya. Selain itu terdapat perbedaan pada variabel yang digunakan. Peneliti terdahulu berfokus pada minat muzakki membayar zakat pada UPZ, sedangkan peneliti berfokus pada tingkat penerimaan dana zakat pada BAZNAS. Tujuan dilakukannya penelitian ini yakni untuk mengetahui apakah terdapa kaitan/pengaruh antar setiap variabelnya dalam tingkat penerimaan dana zakat.

Berdasarkan uraian yang dipaparkan, ruusan masalah yang dapat dikaji yakni : 1) apakah kualitas informasi akuntansi berpengaruh positif terhadap tingkat penerimaan dana zakat?, 2) apakah akuntabilitas berpengaruh positif terhadap tingkat penerimaan dana zakat? dan 3) apakah transparansi pelaporan keuangan berpengaruh positif terhadap tingkat penerimaan dana zakat?. Tujuan dilakukannya penelitian ini yaitu agar mengetahui apakah kualitas informasi akuntansi, akuntabilitas dan transparansi pelaporan keuangan secara parsial berpengaruh positif terhadap tingkat penerimaan dana zakat pada BAZNAS Kabupaten Buleleng.

Kualitas dari informasi akuntansi yang digunakan bisa dilihat mellaui informasi yang dihasilkan oleh lembaga tersebut. Suatu kualitas dari informasi dilihat dari tiga prinsip yaitu: tepat waktu, akurat serta relevan. Yang dimaksud relevan disini memiliki arti bahwa suatu informasi harus memiliki manfaat bagi penggunanya. Tepat waktu, memiliki arti bahwa informasi tersebut disajikan sesuai pada waktu yang ditentukan kepada penerima dan tidak 
terlambat. Akurat, mempunyai arti bahwa informasi yang disajikan tidak terdapat kekeliruan serta tidak memihak (Rahayu, 2019). Kualitas dari suatu informasi akuntansi akan sangat dibutuhkan oleh para muzakki, dimana suatu organisasi dikatakan memiliki kualitas informasi yang tinggi, apabila memiliki ciri akurat, relevan, tepat waktu, dan lengkap. Dapat dikatakan bahwa penerimaan dana zakat bergantung pada kualitas informasi yang telah dilaksanakan dalam BAZNAS. Dengan demikian, melalui paparan yang telah diuraikan dapat diambil hipotesis pertama yaitu :

H1 : Kualitas Informasi Akuntansii Berpengaruh Positif Terhadap Tingkat Penerimaan Dana Zakat

Kemudian, terkait dengan pengaruh akuntabilitas terhadap tingkat penerimaan dana zakat. Akuntabilitas merupakan suatu kewajiban bagi agen untuk memperhatikan stakeholder atas kegiatan dan pencapaian dalam suatu Organisasi, Lembaga, dan Perusahaan. Prinsip Akuntabilitas memberi kepastian kepada publik untuk dapat mengetahui dana-dana yang telah diterima oleh BAZNAS selama beberapa periode (Nikmatuniayah, Marliyati dan Mardiana, 2017:63). Semakin tinggi akuntabilitas dalam laporan keuangan maka, semakin tinggi pula tingkat penerimaan dana zakat. Apabila BAZNAS akuntabel terhadap masyarakat maka akan dapat menambah kepercayaan masyarakat untuk membayar zakatnya di BAZNAS serta hal tersebut akan menambah penerimaan dana zakat. Dengan demikian, dari paparan yang telah diuraikan dpata diambil hipotesis kedua yaitu:

H2 : Akuntabilitas Berpengaruh Positif Terhadap Tingkat Penerimaan Dana Zakat

Selanjutnya, tranparansi dalam laporan keuangan sangatlah dibutuhkan oleh semua muzakki agar muzakki percaya terhadap unit pengumpul zakat terhadap beasaran zakat yang dibayarnya. Transparansi sangat wajib untuk diterapkan, karena prinsip ini juga merupakan salah satu dari good governance. Transparansi dibentuk berdasarkan hak dalam mendapatkan informasi mengenai kebutuhan publik bagi pemakai informasi. Sehingga informasi yang dibutuhkan dapat diperoleh dengan lebih mudah. Semakin baik organisasi pengelola zakat menerapkan prinsip transparansi maka akan dapat meningkatkan penerimaan dana zakat. Dengan demikian, melalui paparan yang telah diuraikan, dapat diambil hipotesis ketiga yaitu:

H3 : Transparnsi Pelaporan Keuangan Berpengaruh Positif Terhadap Tingkat Penerimaan Dana Zakat

\section{Metode}

Dalam hal metode, metode digunakan yaitu metode kuantitatif. Dimana, populasinya yaitu seluruh muzakki (penerima zakat) yang membayarkan zakatnya pada BAZNAS KabupatenBuleleng. Sampelnya yaitu muzakki yang dirasa dapat bisa memberikan informasi yang dibutuhkan oleh peneliti dengan menggunakan beberapa pertimbangan, dimana pada hal ini yang di maksud adalah muzakki yang pernah membayar zakatnya mellaui BAZNAS Kabupaten Buleleng.

Dalam pemilihan sampel digunakan teknik purposive, sehingga didapatkan sejumlah 182 muzakki yang dapat berpartisipasi pada pencarian data ini. Dalam pencarian data digunakan dengan pembagian kusioner secara langsung dan melalui google form serta disusun dengan skala likert dari 1 sampai 5.

Adapun teknik yang digunakan dalam menganalisis datayang didapatkan yaitu : uji kualitas data, analisis deskriptif, uji asumsi klasik serta uji hipotesis. Pengujian data yang pertama yakni pengujian validitas serta reabilitas. Yang kedua, yakni analisis deskriptif. Selanjutnya, yaitu ujiasumsi klasik terdiri dari uji normalitas, uji multikolonearitas serta uji heteroskedastisitas. Yang terakhir adalah pengujian hipotesis mencakup analisi regresi berganda, uji t dan koefesien determinasi. Data yang terkumpul akan diolah dengan alat ukur statistik karena merupakan metode kuantatitatif sehingga dapat diukur menggunakan SPSS versi 24. 
VJRA, VOL.9, NO.2, Oktober 2020

p-ISSN:2337-537X : e-ISSN:2686-1941

\section{Hasil Dan Pembahasan}

Dari data yang terkumpul dari 182 muzakki yang pernah membayar zakatnya di Kabupaten Buleleng. Dimana data yang disebar kepada responden berupa kuisioner yang dilakukan secara langsung dan melalui online dengan menggunakan media google form. Pengiriman kuisioner secara langsung sebanyak 22 kuisioner dan sisanya melalui kuisioner online atau google form. Tidak terdapat kuisioner yang gugur atau tidak lengkap, yang dimana seluruh kuisioner layak untuk dianalisis dengan tingkat useable response rate adalah $100 \%$.

Dari data yang terkumpul dapat diketahui jumlah responden sebanyak 182 responden, yang dapat diklasifikasikan berdasarkan gender nya laki-laki sejumlah 94 orang dan perempuan sejumlah 88 orang. . Dari data yang tekumpul, yang telah mengisi kuesioner juga sudah memenuhi kriteria yaitu berusia diatas 17 tahun, pernah membayar zakat secara langsung maupun melalui online pada BAZNAS Kabupaten Buleleng serta pernah melihat atau membaca laporan keuangan BAZNAS Kabupaten Buleleng. Dari 182 responden tersebut dikatakan telah memenuhi kriteria yang telah ditentukan sehingga hasil kuesioner sepenuhnya layak dan dapat di jadikan sampel penelitian untuk kemudian diolah datanya ke tahap analisis data.

Pengujian pertama yang dilakukan yaitu pengujian validitas. Tujuan dari pengujian ini yaitu untuk mengukur kualitas data yang diperoleh dalam penelitian, melaui teknik korelasi yakni Pearson's Correlation yang di analisis dengan suatuprogram SPSS 24.0 for Window.. Apabila nilaisig. $<\alpha=0,05$, maka semua pernyataan dalam kuisioner pada variabel kualitas informasi akuntansi, akuntabilitas, transparansi pelaporan keuangan serta tingkat penerimaan dana Zakat dinyatakan valid.

Uji reliabilitas, dimana pengujian ini digunakan dalam menguji kusioner dimana apabila kita menggunakan untuk mengukur objek, data yang dihasilkan antara objek yang satu dengan yang lainnya menghasilkan data yang sama. Reliabel dapat dilihat apabila Alpha Cronbach $>0,70$. Berdasarkan yang sudah di analisis bisa ditarik kesimpulan bahwasannya kuisioner kualitas informasi akuntansi, akuntabilitas, tranparansi pelaporan keuangan serta tingkat penerimaan dana zakat adalah reliabel.

Berdasarkan data yang telah didapatkan hasil dari penelitian ini memiliki deskripsi umum yang mencakup hasil analisis statistik deskripstif. Untuk dapat memberikan gambaran mengenai variabel-variabel yang akan teliti di butuhkan analisis deskriptif. Hasil analisis deskriptif menunjukkan bahwa data kualitas informasi akuntansi mempunyai nilai minim 34 serta nilai maksimal 50. Nilai rata-rata 41,65 dari standr devias 2,83. Apabila nilai dari stndar devasi lebih kecil dari nilai rata-rata maka penyebaran kuisioner kualitas informasi akuntansi pada penelitian ini terdistribusi rata. Pada variabel akuntabilitas memiliki nilai minimum 45 serta nilai maksimum 60. Skor rata-rata 53,91 standar deviasi sebesar 2,87. Dapat dilihat bahwa nilai skor rata-rata dalam persebaran data akuntabilitas dapat dikatakan merata, dengan demikian jarak antar data Standar deviasi lebih kecil dan jarak antar data tidak teralu tinggi. Selanjutnya pada variabel transparansi pelaporan keuangan mempunyai nilai minimum 37 dan nilaimaksimum 55. nilai rata-rata 45,93 dengan standar devias 2,95. Dapat dilihat bahwa nilai skor rata-rata dalam persebaran data transparansi dapat dikatakan merata, dengan demikian jarak antar data Standar deviasi lebih kecil serta jarak antar data tidak teralu tinggi. Dan yang terakhir data tingkat penerimaan dana Zakat mempunyai nilai minimum 39 dan nilai maksimum 52. Sor rata-rata 45,29 denganstandar deviasi 2,36. Dapat dilihat bahwa nilai skor rata-rata dalam persebaran data tingkat penerimaan dana zakat dapat dikatakan merata, dengan demikian jarak antar data Standar deviasi lebih kecil serta jarak antar data tidak teralu tinggi.

Sebaran data pada uji normalitas digunakan One Sample Kolmogorov Smirnov Test. Pengujian ini menggunakan unstandardized residual. Dimana berdasarkan uji tersebut didapatkan hasil Nilai Sig. sebesar 0,200 yang dimana Nilai Sig. tersebut lebih besar dari 0,05 untuk statistik Kolmogorov-Smirnov $Z$ maka dapat ditarik kesimpulan bahwasannya penyebaran data penelitian ini berdistribus normal.

Vokasi : Jurnal Riset Akuntansi | 85 
Dari uji multikolinieritas yang digunakan Variance Inflation Factor (VIF). diketahui bahwasannya nilai VIF setiap variabelbebas lebih kecil dari 10 serta nilai tolerance lebih 0,10 . Maka dariitu, disimpulkan bahwa tidak terjadi multikolinearitas. Pengujian berikutnya yaitu heteroskedastisitas. Dalam Menguji heteroskedastisitasmenggunakan uji Glejser. Dengan menggunakan uji tersebut diketahui bahwa nilai sig. antara variabel bebas terhadap absolute residual (ABS) lebih besar dari 0,05. Jadi, dapat disimpulkan bahwa model regresi yang digunakan dalam penelitian ini tidak terdapat adanya gejala heteroskedastisitas.

Ketika semua uji yang dilakukan telah memenuhi, maka selanjutnya dilakukan pengujian hipotesis, dimana pengujian hipotesis yang pertama dilakukan adalah analisis regresi linear berganda. Berdasarkan hasil analisis regresi linier berganda dapat diketahui persamaan garis regresi dengan menggunakan analisis konstanta dan koefisien beta. Berdasarkan perhitungan regresi linier berganda maka di dapatkan hasil daripersamaan berikut:

$\mathrm{Y}=7,450+0,208 \mathrm{X} 1+0,344 \mathrm{X} 2+0,231 \mathrm{X} 3+\varepsilon$

Degresi yang dibentuk, dapat dijelaskan hasilyang diidapat yakni: 1) Konstanta 7,450 menunjukan jika variabelkualitas informasi akuntansi $\left(X_{1}\right)$, akuntabilitas $\left(X_{2}\right)$, transparansi pelaporan keuangan $\left(\mathrm{X}_{3}\right)$ bernilai konstan, maka variabel tingkat penerimaan dana Zakat $(Y)$ memiliki nilai 7,450 satuan. 2) Kualitas informasi akuntansi $\left(X_{1}\right)$ memipunyai koefisien regresi 0,208 . Nilai koefisien regresi yang positif menunjukkan kualitas informasi akuntansi $\left(X_{1}\right)$ berpengaruh positif terhadap tingkat penerimaan dana Zakat $(Y)$. Ini menggambarkan bahwa setiap kenaikan 1 satuan kualitas informasi akuntansi $\left(X_{1}\right)$ dapat meningkatkan tingkat penerimaan dana Zakat $(Y)$ sebesar 0,208 dengan asumsi variabel independen yang lainnya tetap. 3) Akuntabilitas $\left(X_{2}\right)$ memiliki koefisien regresi 0,344 . Nilai koefisien regresi yang positif menunjukkan bahwa akuntabilitas $\left(\mathrm{X}_{2}\right)$ berpengaruh positif terhadap tingkat penerimaan dana Zakat $(\mathrm{Y})$. Hal ini menunjukkan bahwasannya pada kenaikan 1 satuan akuntabilitas $\left(\mathrm{X}_{2}\right)$ bisa meningkatkan tingkat penerimaan dana Zakat $(\mathrm{Y})$ sebesar 0,344 dengan asumsi variabel independen yang lainnya tetap. 4) Transparansi pelaporan keuangan $\left(X_{3}\right)$ memiliki koefisien regresi 0,231. Nilai koefisien regresi yang positif menunjukkan bahwa transparansi pelaporan keuangan $\left(X_{3}\right)$ berpengaruh positif terhadap tingkat penerimaan dana Zakat (Y). Hal ini menggambarkan bahwa setiap kenaikan 1 satuan transparansi pelaporan keuangan $\left(\mathrm{X}_{3}\right)$ dapat meningkatkan tingkat penerimaan dana Zakat (Y) sebesar 0,231 dengan asumsi variabel independen yang lainnya tetap. Untuk lebih jelasnya hasil analisis data dapat dilihat di tabel 1

Tabel 1. Hasil Analisis Koefisien Beta dan Uji t

\begin{tabular}{|c|c|c|c|c|c|c|}
\hline & \multirow[t]{2}{*}{ Model } & \multicolumn{2}{|c|}{$\begin{array}{l}\text { Unstandadized } \\
\text { Coefficients }\end{array}$} & \multirow{2}{*}{$\begin{array}{c}\begin{array}{c}\text { Standadized } \\
\text { Coefficients }\end{array} \\
\text { Beta }\end{array}$} & \multirow[t]{2}{*}{$t$} & \multirow[t]{2}{*}{ Sig. } \\
\hline & & $B$ & Std Error & & & \\
\hline \multirow[t]{4}{*}{1} & (Constant) & 7,450 & 2,041 & & 3,650 & 0,000 \\
\hline & $\mathrm{X}_{1}$ & 0,208 & 0,046 & 0,249 & 4,573 & 0,000 \\
\hline & $X_{2}$ & 0,344 & 0,049 & 0,418 & 7,061 & 0,000 \\
\hline & $X_{3}$ & 0,231 & 0,046 & 0,289 & 4,984 & 0,000 \\
\hline
\end{tabular}

Keterangan: $\mathrm{X}_{1}=$ kualitas informasi akuntansi, $\mathrm{X}_{2}=$ akuntabilitas, $\mathrm{X}_{3}=$ transparansi pelaporan keuangan, dan $\mathrm{Y}=$ tingkat penerimaan dana Zakat

Uji t berfungsi agar menentukan analisis seberapa besar pengaruhkualitas informasi akuntansi, akuntabilitas serta transparansi pelaporan keuangan terhadap tingkat penerimaan dana Zakat secara parsial. Dimana hasil yang didapat dari pengujian untuk hipotesis pertama kualitas informasi akuntansi mempunyai nilai sig. uji t sebesar 0,000, nilai tersebut lebih kecil dari 0,05 sehingga $\mathrm{H}_{1}$ dapatditerima. Jadi, bisa disimpulkan bahwa kualitas informasi akuntansi berpengaruh positif terhadap tingkat penerimaan dana Zakat. Hasil pengujian hipotesis kedua menunjukkan bahwa akuntabilitas memiliki nilai signifikansi uji $t$ sebesar 0,000 , dimana nilai tersebut lebih kecil dari 0,05 sehingga $\mathrm{H}_{2}$ diterima. Jadi, dapat 
disimpulkan bahwasannya akuntabilitas berpengaruh positif terhadap tingkat penerimaan dana Zakat.

Selanjutnya yaitu pengujian hipotesis ketiga menyatakan bahwasannya transparansi pelaporan keuangan mempunyaii nilai sig. uji t sebesar 0,000, nilainya lebih kecil dari 0,05 sehingga $\mathrm{H}_{3}$ diterima. Jadi, dapat disimpulkan bahwa transparansi pelaporan keuangan berpengaruh positif terhadap tingkat penerimaan dana Zakat dan untuk lebih jelasnya mengenai hasil analisis uji t bisa dilihat pada tabel 1.

Hasil uji koefesien determinasii menunjukkan bahwa nilai koefisien determinasi sebesar 0,657 . Hal ini menunjukkan bahwa $65,7 \%$ variabel tingkat penerimaan dana Zakat dipengaruhi oleh variabel kualitas informasi akuntansi, akuntabilitas, transparansi pelaporan keuangan, sedangkan 34,3\% kemungkinan berdasarkan faktorlain. Untuk lebih jelasnya bisa dilihat pada tabel berikut

Tabel 2. Hasil Koefisien Determinasi

\begin{tabular}{ccccc}
\hline Model & $\mathrm{R}$ & $\mathrm{R}$ Square & $\begin{array}{c}\text { Adjusted } \mathrm{R} \\
\text { Square }\end{array}$ & Std. Error of the Estimate \\
\hline 1 & 0,814 & 0,662 & 0,657 & 1,385 \\
\hline
\end{tabular}

\section{Pengaruh Kualitas Informasi Akuntansi Terhadap Tingkat Penerimaan Dana Zakat}

Pengujian hipotesis pertama mengenai keterkaitan antara variabel bebas pertama terhadap tingkat penerimaan dana zakat memperlihatkan nilaikoefisien regresi sebesar 0,208 dengn nilai signifikansi uji t sebesar 0,000. Dengan demikian, hipotesis pertama dalam penelitian diterima. Hal ini dapat menytakan bahwsannya kualitas informasi akuntansi berpengaruh positif terhadap tingkat penerimaan dana Zakat.

Kualitas dari informasi akuntansi yang digunakan bisa dilihat mellaui informasi yang dihasilkan oleh lembaga tersebut. Suatu kualitas dari informasi dilihat dari tiga prinsip yaitu: tepat waktu, akurat serta relevan. Yang dimaksud relevan disini memiliki arti bahwa suatu informasi harus memiliki manfaat bagi penggunanya. Tepat waktu, memiliki arti bahwa informasi tersebut disajikan sesuai pada waktu yang ditentukan kepada penerima dan tidak terlambat. Akurat, mempunyai arti bahwa informasi yang disajikan tidak terdapat kekeliruan serta tidak memihak (Rahayu, 2019).

Kualitas informasi akuntansi akan sangat dibutuhkan oleh para muzakki, dimana suatu organisasi dikatakan memiliki kualitas informasi yang tinggi, apabila memiliki ciri akurat, relevan, tepat waktu, dan lengkap (Novianti, 2019). Dapat dikatakan bahwa penerimaan dana zakat bergantung pada kualitas informasi yang telah dilaksanakan dalam Badan Amil Zakat Nasional (BAZNAS).

Penelitian Novianti (2019), menunjukkan bahwa semkain tinggi atau semakin baik informasi akuntansi dalam suatu OPZ, dapat dikatakan jumlah pembayaran zakat akan meningkat pula. Penelitian Natalia (2019), menyatakan bahwasannya kualitas informasi akuntansi memiliki pengaruh signifikan pada dana zakat yang diterima. Pada penelitian Nurhayati dkk (2014), menyatakan bahwa informasi akuntansi memiliki pengaruh positif pada dana zakat.

Dilihat dari penelitian-penelitian sebelumnya peneliti mengambil kesimpulan apabila kualitas informasi akuntansi yang digunakan pada BAZNAS tinggi maka akan dapat membuat muzakki akan menyerahkan zakatnya pada BAZNAS serta hal tersebut akan meningkatkan penerimaan dana zakat.

\section{Pengaruh Akuntabilitas Terhadap Tingkat Penerimaan Dana Zakat}

Selanjutnya tentang pengaruh akuntabilitas terhadap tingkat penerimaan dana Zakat memperlihatkan nilai koefisien regresi sebesar 0,344 yang dimana nilai signifiknsi uji $t$ 0,000 . Maka, hipotes kedua pada penelitian i diterima. Hal ini memperlihatkan bahwasannya akuntabilitas memilik pengaruh positif pada tingkat penerimaan dana Zakat.

Akuntabilitas merupakan suatu kewajiban bagi agen untuk memperhatikan stakeholder atas kegiatan dan pencapaian dalam suatu Organisasi, Lembaga, dan Perusahaan. Prinsip 
Akuntabilitas memberi kepastian kepada publik untuk dapat mengetahui dana-dana yang telah diterima oleh BAZNAS selama beberapa periode (Nikmatuniayah, Marliyati dan Mardiana, 2017:63). Bentuk pertanggungjawaban aktivitas dalam suatu organisasi disajikan dengan menggunakan laporan keuangan yang diberikan kepada intansi yang diberi amanah agar mencapai tujuan yang telah ditetapkan organisasi (Natalia, 2019).

Nikmatuniayah dkk (2017) dalam penelitiannya menyatakan bahwasannya semakin tinggi akuntabilitas dalam laporan keuangan maka, semakin tinggi pula tingkat penerimaan dana zakat. Nurhayati dkk (2016) menyatakan akuntabilitas memiliki pengaruh terhadap penerimaan dana zakat. Septarini (2011) bahwa akuntabilitas mempunyai pengaruh positif pada penerimaan dana zakat.

Dilihat dari semua penelitian sebelumnya, maka dapat mengambil kesimpulan bahwa apabila BAZNAS akuntabel terhadap masyarakat maka akan dapat meningkatkan kepercayaan masyarakat dalam menyerahkan zakat pada BAZNAS serta hal tersebut akan meningkatkan penerimaan dana zakat.

\section{Pengaruh Transparansi Pelaporan Keuangan Terhadap Tingkat Penerimaan Dana Zakat}

Pengujian hipotesis ketiga menunjukan nilai koefisien regresi sebesar 0,231 dengan nilai signifikansi uji t sebesar 0,000. Dengan demikian, hipotesis ketiga dalam penelitian diterima. Hal ini memperlihatkan bahwasannya transparansi pelaporan keuangan berpengaruh positif terhadap tingkat penerimaan dana Zakat.

Selanjutnya, transparansi dalam laporan keuangan sangatlah dibutuhkan oleh semua muzakki agar muzakki percaya terhadap unit pengumpul zakat terhadap beasaran zakat yang dibayarnya. Transparansi sangat wajib untuk diterapkan, karena prinsip ini juga merupakan salah satu dari good governance. Transparansi dibentuk berdasarkan hak dalam mendapatkan informasi mengenai kebutuhan publik bagi pemakai informasi. Sehingga informasi yang dibutuhkan dapat diperoleh dengan lebih mudah. Semakin baik organisasi pengelola zakat menerapkan prinsip transparansi maka akan dapat meningkatkan penerimaan dana zakat. Transparansi diterapkan berdasarkan hak untuk mendapatkan data terkait pada segala keperluan para pemakai informasi, sehingga informasi yang dibutuhkan dapat diperoleh dengan lebih mudah (Renyowijoyo, 2013).

Penelitian Novianti (2017) menyatakan bahwa tranparansi laporan keuangan berpengaruh signifikan pada tingkat penerimaan dana zakat. Nurhayati dkk (2014) bahwasannya transparansi memiliki pengaruh positif pada tingkat penerimaan dana zakat. Berdasarkan penelitian-penelitian sebelumnya peneliti mengambil kesimpulan bahwa apabila Badan Amil Zakat Nasional (BAZNAS) transparansi pada masyarakat maka akan mampu membuat pemberi zakat percaya agar menyerahkan zakatnya terhadao unit pengumpul zakat serta hal tersebut akan meningkatkan penerimaan dana zakat.

\section{Simpulan dan Saran}

Dilihat dari hasil yang didapat melalui pengujian menganalisis regresi linier berganda dapat disimpulkan hal-hal berikut: Hasil analisis regresi linier berganda yang pertama mengenai pengaruh kualitas informasi akuntansi (X1) terhadap tingkat penerimaan dana zakat menunjukkan koefisien regresi sebesar 0,208 dengan nilai signifikansi uji t sebesar 0,000 . Secara parsial variabel kualitas informasi akuntansi berpengaruh positif terhadap tingkat penerimaan dana zakat. Artinya semakin baik kualitas informasi akuntansi pada BAZNAS Kabupaten Buleleng, maka semakin tinggi pula tingkat penerimaan dana zakat yang diterima oleh BAZNAS Kabupaten Buleleng.

Pada pengujian regresi linier berganda mengenai kedua mengenai pengaruh akuntabilitas (X2) terhadap tingkat penerimaan dana zakat menyatakan koefisen regresi sebesar 0,344 pada nilai signifikansi uji t sebesar 0,000. Secara parsial variabel akuntabilitas berpengaruh positif pada tingkat penerimaan dana zakat. Artinya, semakin tinggi penerapan akuntabilitas pada BAZNAS Kabupaten Buleleng, maka semakin tinggi pula jumalh dana zakat yang diterima pada BAZNAS Kabupaten Buleleng. 
Hasil analisis regresi linier berganda yang ketiga mengenai pengaruh transparansi pelaporan keuangan (X3) terhadap tingkat penerimaan dana zakat menunjukkan koefisien regresi sebesar 0,231 dengan nilai signifikansi uji t sebesar 0,000. Secara parsial variabel transparansi pelaporan keuangan berpengaruh positif pada tingkat penerimaan dana zakat. Artinya, makin besar penerapan transparansi pada BAZNAS Kabupaten Buleleng, maka semakin tinggi pula tingkat penerimaan dana zakat yang diterima oleh BAZNAS Kabupaten Buleleng.

Saran yang dapat diberikan dalam penelitian terhadap BAZNAS Kabupaten Buleleng maupun bagi peneliti selanjutnya yaitu, pertama, bagi BAZNAS Kabupaten Buleleng agar dapat meningkatkan serta mempertahankan dari penggunaan kualitas informasi akuntansi, akuntabilitas serta transparansi dalam pelaporan keuangan dengan tujuan agar muzakki merasa aman dan percaya terhadap dana zakat yang diberikan serta agar lebih banyak muzakki yang membayar zakatnya melalui BAZNAS Kabupaten Buleleng. Serta lebih meningkatkan sosialasi kepada masyarakat, seperti meningkatkan kegiatan amal yang lebih rutin agar masyarakat Islam sekitar lebih memiliki kesadaran untuk membayar zakatnya. Kedua, Bagi peneliti selanjutnya diharapkan memperluas atau memperbanyak objek penelitian yang digunakan, tidak hanya satu wilayah atau satu organisasi pengelola zakat saja. Misalnya, melakukan penelitian pada Lembaga Amil Zakat (LAZ), Baitul Maal, rumah zakat. Serta mencari variabel yang berbeda yang dirasa akan berpengaruh terhadap tingkat penerimaan dana zakat, seperti variabel sosialisasi, kepercayaan, serta religuitas.

\section{Daftar Pustaka}

Ayuningtyas dan Deddi. 2010. Akuntansi Sektor Publik. Jakarta: Salemba Empat.

Hamidi, N., dan Suwardi, E. 2013. Analisis Akuntabilitas Publik Organisasi Pengelola Zakat Berdasarkan Aspek Pengendalian Intern dan Budaya Organisasi pada Organisasi Pengelola Zakat di Indonesia. Jurnal Ekonomi dan Bisnis Islam, Vol VIII No. 1.

Mardiasmo. (2002). Akuntansi sektor publik. Yogyakarta: CV Andi.

Nugraha, 2019. Pengaruh Akuntabilitas, Transparansi dan Kualitas Pelayanan Lembaga Pengelola Zakat Terhadap Komitmen Muzakki: Kepercayaan Muzakki Sebagai Variabel Intervening. Jurnal Penelitian dan Pengembangan Akuntansi, Vol. 13 No. 2 Juli (2019).

Nurhisamuddin. (2017) Transparansi dan Pelaporan Keuangan Lembaga Zakat. ZISWAF, Vol. 4, No. 2, Desember 2017.

Rahayu, Sri. 2019. Kualitas Informasi Akuntansi Dan tingkat Penerimaan Dana Zakat Pada Lembaga Amil Zakat Di Kota Medan. Jurnal Investasi Islam, Vol. IV No. 2: 1-11.

Sugiyono. 2017. Metode Penelitian Kuantitatif, Kualitatif, dan R\&D. Bandung: Alfabeta.

Triyani, 2017. Manajemen Risiko Pada Badan Amil Zakat Nasional (BAZNAS). Jurnal AlMuzara'ah, Vol. 5 No. 2: 1-18.

Umah, 2011. Penerapan Akuntansi Zakat Pada Lembaga Amil Zakat (Studi Pada LAZ DPU DT Cabang Semarang). Jurnal Unimus, Vol. 7, No. 2.

Yuliafitri, 2016. Pengaruh Kepuasan Muzakki, Transparansi dan Akuntabilitas Pada Lembaga Amil Zakat Terhadap Loyalitas Muzakki (Studi Persepsi Pada LAZ Rumah Zakat). Jurnal Ekonomi Islam, Volume 7 No 2: 1-13.

Hamidi, N., dan Suwardi, E. 2013. Analisis Akuntabilitas Publik Organisasi Pengelola Zakat Berdasarkan Aspek Pengendalian Intern dan Budaya Organisasi pada Organisasi Pengelola Zakat di Indonesia. Jurnal Ekonomi dan Bisnis Islam, Vol VIII No. 1. 